children in a healthy way of living in a healthy environment]. Lviv, 136 p. [in Ukrainian].

11. Mitina, L.M. (2001). Emosionalna gibkost ychitela: Psichologicheskoe soderzanie, diagnostika. [Emotional flexibility of the teacher: psychological content, diagnosis, correction]. Moscov, 190 p. [in Russian].
12. Maslach, C. \& Golberg, J. (1998). Prevention of burnout: New perspectives. Applied and preventive Psychology. Vol. 7. pp. 63-74. [in English].

13. Maslach, C., (1978) (б). Job burnout: How people cope. Public Welfare. 36(2). pp. 56-58. [in English].

Стаття надійшла до редакції 22.03.2019

УДК 373.3.015.3:159.955

DOI:

Оксана Шквир, доктор педагогічних наук, доиент, професор кафедри педагогіки Хмельницької гуманітарно-педагогічної академї

\title{
КРИТИЧНЕ МИСЛЕННЯ МОЛОДШИХ ШКОЛЯРІВ: СУТНІСТЬ І ОСОБЛИВОСТІ
}

У статті акиентовано увагу на проблемі переорієнтачії освітнього прочесу початкової школи на забезпечення ефективних умов для розвитку в учнів критичного мислення. Уточнено сутність понять “мислення” $i$ “критичне мислення”. Визначено структуру критичного мислення: постановка проблеми, пошук інформації, чітка аргументачія, прийняття рішення. Розкрито зміст кожного структурного компонента та визначено роль учителя початкової школи на кожномуз них. Визначено особливості критичного мислення молодших школярів, як-от: самостійність, аналітичність, логічність, соиіальність.

Ключові слова: молодші школярі; мислення; критичне мислення; інтелектуальні техніки; комунікативні техніки; структура критичного мислення; особливості критичного мислення.

Табл. 1. Рис. 1. Літ. 15.

Oksana Shkvyr, Doctor of Sciences (Pedagogy), Associate Professor, Professor of the Pedagogy Department Khmelnytskiy Humanitarian-Pedagogical Academy

\section{CRITICAL THINKING OF JUNIOR SCHOOLCHILDREN: ESSENCE AND PECULIARITIES}

The article focuses on the problem of reorientation of the educational process of the primary school to ensure effective conditions for the development of critical thinking of schoolchildren. The necessity of comparing and generalizing the existing theory of critical thinking, defining the content of the essence "critical thinking" and its peculiarities has been proved. The essence of the concept "thinking" has been specified. It is revealed that one of its types is critical thinking. The significance of critical thinking in human life has been revealed. The necessity of using the method of content analysis for clarification of the concept "critical thinking" has been proved. According to the results of content analysis, the categorical features of this concept have been determined. The author's definition of the concept "critical thinking" has been proposed: scientific thinking, aimed at making the person's own decision by using intellectual and communicative techniques. It is revealed that critical thinking begins with the formulation of a problem (judgment) that needs to be solved; continues to search and comprehension of the information (arguments); construction of convincing argumentation; ends with making the decision (conclusion) as for the resolving of the issue. The structure of critical thinking has been defined: problem statement, information search, clear argumentation, decision making. The content of each structural component has been revealed and the role of a primary school teacher has been defined on each of them. The peculiarities of critical thinking of junior schoolchildren, such as: independence, analyticity, logic, sociality, have been determined. The idea is that the teacher should pay attention to the development of not only the pupils' intellectual and communicative techniques, but also personal qualities necessary for productive exchange of ideas: openness to the perception of other thoughts, tact, tolerance, and mobility. It is noted that the further scientific research requires the study of the purpose, content, methods and forms of development of critical thinking of junior schoolchildren.

Keywords: junior schoolchildren; thinking; critical thinking; intellectual technologies; communicative techniques; a structure of critical thinking; peculiarities of critical thinking.

П остановка проблеми. Зміни, що відбуваються у сучасному українському освітньому середовищі, відбивають тенденції розвитку світової освіти, вимагають від учителів переорієнтації освітнього процесу на забезпечення ефективних умов для розвитку в учнів критичного мислення, про що йдеться в Концепції Нової української школи (2016). Адже критичне мислення $є$ не тільки наслідком демократичного способу життя, але й чинником 
його формування. Тому сьогодні пріоритетними стають здатність і готовність людини аналізувати отримануінформацію, перевіряти й переосмислювати iii, самостійно з'ясовувати істину, ухвалювати рішення й аргументовано захищати свою позицію. Ці завдання $є$ актуальними на кожному етапі шкільної освіти, а іiі початкова ланка $\epsilon$ фундаментом розвитку критичного мислення. Вчитель початкової школи має виховувати мислячу та творчу особистість, яка здатна на критично-конструктивне бачення навколишнього світу і своєї ролі у ньому.

Аналіз останніх досліджень. У витоків проблеми критичного мислення стояли такі видатні вчені як Б. Блум, Л. Бренер Л. Виготський, В. Давидов, Дж. Дьюї, Д. Ельконін, М. Коул та ін. Технологія розвитку критичного мислення розроблена наприкінці XX ст. в США такими вченими, як К. Мередіт, Дж. Стіл, Ч. Темпл та ін. На важливість проблеми критичного мислення вказує і вітчизняний досвід, висвітлений у працях М. Красовицького, О. Пометуна, Ю. Стежко, I. Сущенко, О. Тягло та ін. Технологіям розвитку критичного мислення молодших школярів присвятили свої праці Ш. Амонашвілі, О. Барабаш, Н. Глинянюк, Р. Матоніна та ін.

Однак аналіз їх праць засвідчив наявність різних підходів до тлумачення поняття “критичне мислення” та характеристики його особливостей. Тому виникає необхідність у порівнянні та узагальненні існуючої теорії критичного мислення, що буде сприяти ясному і чіткому розумінню мети, змісту, методів та форм розвитку критичного мислення молодших школярів.

Мета статті полягає в узагальненні теорії критичного мислення, визначенні змісту поняття “критичне мислення” та його особливостей.

Виклад основного матеріалу. Інтелектуальний розвиток людини визначається не обсягом відомостей, утримуваних у пам'яті, а готовністю людини до відбору необхідних знань шляхом критичного аналізу, осмислення інформації й умінням самостійно приймати рішення. Тому в сучасній школі, зокрема початковій, головне завдання вчителя - не накопичення дитиною суми знань, а засвоєння нею інтелектуальних технік, що $є$ складовою культури мислення. Серед сучасних вимог до обов'язкових результатів навчання в початковій школі визначаємо уміння самостійно мислити.

Згідно з українським педагогічним словником, мислення - це вища форма відображення дійсності в психіці, ідеальна діяльність, результатом якої $є$ об’єктивна істина [3, 200].

У широкому розумінні мислення - це вища форма активного відображення дійсності, яка полягає в цілеспрямованому, опосередкованому і узагальненому пізнанні істотних властивостей, зв'язків і відношень предметів і явищ. У вузькому розумінні мислення - це діяльність розуму [13, 6 - 7].

Одним із видів мислення, який “максимально оголює різницю між комп'ютером і мозком людини" $є$ критичне мислення $[1,3]$.

Люди, які вміють критично мислити, інтелектуально незалежні, приймають обмірковані рішення, не дозволяють собою маніпулювати, синтезують здобуті знання, уміють простежити зв'язки між явищами, прогнозують наслідки своїх учинків, свідомо оцінюють свої недоліки та переваги.

Поняття “критичне мислення” у науковій і методичній літературі використовується 31956 року, коли Б. Блум розробив таксономію мислення, визначив, які операції на кожному рівні мислення може здійснити мозок людини. Значний вплив на теорію критичного мислення мали положення Л. Виготського про зону наближеного розвитку. Важливими також були ідеї розвивального навчання Д. Ельконіна та В. Давидова щодо самостійного пошуку істини шляхом використання інтелектуальних технік (порівняння, аналіз, оцінювання, узагальнення та ін.).

Критичне мислення - (давньогрецькою крєєки́ $\tau \varepsilon ́ \chi v \eta$ - “мистецтво аналізувати, судження") - це наукове мислення, суть якого полягає в ухваленні ретельно обміркованих та незалежних рішень [5].

Вивчення науково-педагогічної літератури показало, що сьогодні існують різні підходи щодо розкриття змісту поняття “критичне мислення". Учені не дійшли в цьому питанні до єдиної точки зору, тому ми при виділенні категоріальних ознак досліджуваного поняття звернулися до методу контент-аналізу, за допомогою якого було проаналізовано визначення “критичне мислення" 10 авторів. Вивченню піддалися дисертаційні дослідження, психолого-педагогічні словники, окремі наукові публікації. У результаті аналізу було виявлено 30 простих смислових елементів, серед яких було відібрано чотири стійкі ознаки, що характеризують сутність поняття “критичне мислення" (табл. 1).

Так, відомий український дослідник у галузі критичного мислення О. Тягло назвав критичне мислення “найсучаснішою логікою” i запропонував такий варіант його формулювання, у якому воно розглядається як сучасний вид логічної діяльності, що має за мету систематичне вдосконалення процесу і результатів мислення на основі їх критичного аналізу, розуміння й оцінювання [11]. 
Таблиця 1.

Категоріальні ознаки поняття "критичне мислення"

\begin{tabular}{|c|c|c|c|c|c|}
\hline \multirow[t]{2}{*}{$\begin{array}{l}\text { № } \\
n / n\end{array}$} & \multirow[t]{2}{*}{ Категорія (значення терміна) } & \multicolumn{2}{|c|}{$\begin{array}{l}\text { Кількість авторів } \\
\text { (джерел) }\end{array}$} & \multicolumn{2}{|c|}{$\begin{array}{l}\text { Кількість смислових } \\
\text { одиниць аналізу }\end{array}$} \\
\hline & & $\begin{array}{l}\text { Абсолютне } \\
\text { значення }\end{array}$ & $y \%$ & $\begin{array}{c}\text { Абсолютне } \\
\text { значення }\end{array}$ & $y \%$ \\
\hline 1. & $\begin{array}{l}\text { Тип мислення, що характеризується } \\
\text { логічністю та самостійністю }\end{array}$ & 6 & 60,0 & 6 & 20,0 \\
\hline 2. & $\begin{array}{l}\text { Здатність людини аналізувати та } \\
\text { самостійно оцінювати факти }\end{array}$ & 4 & 40,0 & 4 & 13,4 \\
\hline 3. & $\begin{array}{l}\text { Система розумових стратегій і } \\
\text { комунікативних технік }\end{array}$ & 3 & 30,0 & 3 & 10,0 \\
\hline 4. & $\begin{array}{l}\text { Інтелектуально впорядкований процес, } \\
\text { який закінчується прийняттям рішень }\end{array}$ & 2 & 20,0 & 2 & 6,6 \\
\hline
\end{tabular}

Із філософської точки зорукритичне мислення - це вміння логічно мислити та аргументувати власні судження $[9,2]$.

Автори концепції основ критичного мислення (В. Дюков, Л. Пилипчатіна, О. Пометун, I. Сущенко) визначають критичне мислення як здатність людини аналізувати інформацію, події і факти та критично їх оцінювати, формувати власну позицію 3 того чи іншого питання i захищати, обгрунтовувати іiі, знаходити нові ідеї. Це такий тип мислення, що характеризується зваженістю, логічністю і цілеспрямованістю, використанням спеціальних когнітивних умінь і навичок, які збільшують вірогідність отриманого результату розумової діяльності $[10,24]$.

Таке мислення, на їх думку, є нестандартним i передбачає можливість бачити й оцінювати альтернативи, встановлювати пріоритети, визначати достовірність і доцільність інформації, приймати необхідні рішення, коригувати помилки, у тому числі і в процесі власного мислення [10, 24].

Згідно 3 Р. Матоніною, під критичним мисленням треба розуміти здатність людини (природну або виховану) до самостійного оцінювання явищ навколишньої дійсності, наукових знань, думок і тверджень інших людей, уміння визнавати їх позитивні та негативні сторони; а також прагнення до кращого, оптимальнішого розв'язання проблем, до перегляду догм, стереотипів, традицій, що існують $[7,9]$. Водночас вона зазначає, що це складний процес, що починається із залучення інформації, іiі критичного осмислення та завершується ухваленням рішення. Це здатність людини самостійно аналізувати інформацію, уміння бачити помилки або логічні порушення у твердженнях партнерів, аргументувати свої думки, змінювати їх, якщо вони неправильні $[7,6]$. Погоджуємося 3 дослідницею, щодо того, що “критичне мислення виявляється сьогодні тією життєздатною перспективою розвитку “науки мислити”, яка на початку XXI ст. відповідає умовам ефективної життєдіяльності людини інформаційного суспільства" [7, 7].

Заслуговує на увагу таке визначення досліджуваного поняття: критичне мислення - це система розумових стратегій і комунікативних якостей, що дозволяє ефективно взаємодіяти людині з інформаційною реальністю [14, 25].

Психолог Д. Халперн розглядає критичне мислення як використання когнітивних технік або стратегій, які збільшують імовірність одержання бажаного кінцевого результату [12].

М. Скрівен і Р. Пол доповнюють, що це “інтелектуально впорядкований процес активного і умілого аналізу, концептуалізації, застосування, синтезування й оцінки інформації, отриманої або породженої спостереженням, досвідом, міркуванням або комунікацією, як орієнтир для переконання і дії' [15].

В. Волкова вважає критичне мислення мисленням вищого порядку, яке спирається на інформацію, усвідомлене сприйняття власної інтелектуальної діяльності та діяльності інших [4,27].

Н. Наволокова зазначає, що критичне мислення - це вміле відповідальне мислення, що дозволяє людині формулювати надійні вірогідні судження [8, 28].

На думку С. Мартиненко, поняття “критичне мислення" ширше за своєю сутністю за поняття “креативне мислення", “оптимальне мислення”, “динамізм мислення”, оскільки інтегрує в собі всі характеристики мислення, що містяться в них $[6,100]$.

Варто зазначати, що у педагогічній ментальності поняття "критичне мислення" пов'язане з пошуком недоліків. Коли говорять: “Він мислить занадто критично”, то мають на увазі зайву недовірливість людини, їі небажання приймати думки іншої людини. Однак необхідно відрізняти критичне мислення від так званого 


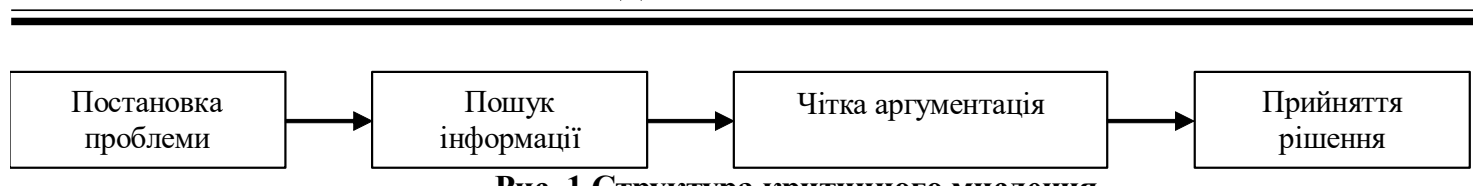

Рис. 1 Структура критичного мислення

“критиканства”. Критичне мислення - це не критика недоліків, а вміння визначати проблему і виробляти оптимальну стратегію іiі розв'язання $[1,3]$.

Отже, на основі здійсненого категорійного аналізу поняття “критичне мислення” ми сформулювали власне визначення цієї дефініції: це наукове мислення, спрямоване на прийняття людиною власного рішення шляхом використання інтелектуальних і комунікативних технік.

Критичне мислення починається з постановки проблеми (судження), яку необхідно розв'язати; продовжується пошуком і осмисленням інформації (аргументів); побудовою переконливої аргументації; закінчується прийняттям рішення (висновку) щодо розв'язання порушеної проблеми.

Керуючись цими думками, нами було визначено структуру критичного мислення (рис. 1).

Постановка проблеми. Критичне мислення починається 3 постановки запитань i формулювання проблеми. Проблемою $є$ ті судження (думки), що піддаються сумніву. Учитель, розробляючи конспект заняття, визначає у змісті навчального чи виховного матеріалу думки, до яких можна сформулювати проблемні питання. Також у процесі взаємодії з учнями, він може піддати сумнівам судження окремих дітей, створивши проблемну ситуацію, до розв'язання якої залучаються всі інші учні. Важливо також ініціювати потребу учнів у постановці запитань до вчителя i формулюванні проблеми, над розв'язанням якої всі будуть працювати.

Пошук інформації. Початок розв'язання проблеми - це збирання інформації про неї. Критичне мислення можливе тоді, коли учень володіє певною інформацією. Знання створюють базу для критичного мислення. Для того, щоб учні висловлювали власні думки, їм потрібно переробити (проаналізувати, порівняти, узагальнити та ін.) значну кількість інформації (факти, ідеї, теорії, правила, життєвий досвід та ін.). На підставі чого учень зможе довести власну думку.

Чітка аргументація. Критичне мислення потребує переконливої аргументації. Одна проблема може мати декілька розв'язань. Тому правильність рішення має бути доведена переконливими чіткими аргументами (судженнями), сформульованими на основі інформації, якою оволодів учень.
Прийняття рішення. Завершується процес розвиткукритичне мислення прийняттям рішення (висновком) щодо оптимального розв'язання поставленої проблеми.

Рішення учня визначається не тільки запасом його знань і вмінь, але й особистісними якостями, психічними установками i, значною мірою, його переконаннями, зокрема навичками рефлексивного ставлення до свого “ $Я$ ”, моральною і соціальною відповідальністю, повагою до індивідуальних особливостей інших учнів $[2,10]$.

Останнім часом вітчизняні вчені активно досліджують особливості критичного мислення як його рефлексивного типу. На основі вивчення науково-педагогічної літератури нами було визначено такі особливості критичного мислення молодших школярів: самостійність, аналітичність, логічність, соціальність.

Самостійність. Мислення стає критичним тільки за тієї умови, якщо носить індивідуальний характер. Більшість молодших школярів отримали дошкільну освіту, постійно оволодівають новими знаннями у школі, з інтернет ресурсів; мають певний життєвий досвід. Тому учні початкових класів здатні на основі інформації, якою вони володіють, самостійно вирішувати визначену проблему. Критичне мислення не обов'язково має бути оригінальним. Учні можуть прийняти ідею або переконання іншоїлюдини, тим самим погодитись із нею.

Аналітичність. Критичне мислення передбачає відбір інформації на основі використання інтелектуальних технік. Учитель має навчити учнів аналізувати, порівнювати, узагальнювати, оцінювати інформацію для того, щоб вони сформулювали власні думки (аргументи) i прийняли самостійне рішення.

Логічність. Аргументи і висновки учнів мають відповідати основним рисам логічного мислення (чіткість, послідовність, несуперечливість, доказовість). За таких умов учень може побудувати правильне міркування і розв'язати визначену проблему.

Cоціальність. Критичне мислення $\epsilon$ соціальним. Кожна думка перевіряється i поглиблюється, якщо вона обговорюється 3 іншими. У результаті чого уточнюється і поглиблюється власна позиція учня. Тому доводити істинність своєї думки учні повинні під час спілкування. Вчителю необхідно навчити 
учнів використовувати комунікативні техніки для доведення істинності власного судження: уміння слухати інших, відстоювати власну точку зору, змінювати власну позицію на підставі контраргументів. Окрім того, вчителю необхідно приділяти увагу розвитку в учнів особистісних якостей, необхідних для продуктивного обміну думками: відкритість до сприйняття інших думок, тактовність, толерантність, мобільність.

Висновки. Отже, критичне мислення молодших школярів - це самостійне, аналітичне, логічне і соціальне мислення, спрямоване на оптимальне розв'язання проблеми, вироблення учнями власного рішення. Воно має свою структуру (постановка проблеми, пошук інформації, чітка аргументація, прийняття рішення) i передбачає використання інтелектуальних і комунікативних технік. Робота вчителя початкової школи має бути спрямована на навчання учнів мислити, висловлювати і доводити власну думку, будувати конструктивні стосунки з іншими дітьми.

Розвиток критичного мислення молодших школярів допомагає готувати дітей нового покоління, які вміють міркувати, спілкуватися, співпрацювати, знаходити нові ідеї.

Подальших наукових розвідок потребує питання вивчення мети, змісту, методів і форм розвитку критичного мислення молодших школярів.

\section{ЛІТЕРАТУРА}

1. Барабаш О., Глинянюк Н. Вчимося міркувати самостійно та розважливо. Учитель початкової школи. 2018. № 11. С. 3-7.

2. Батрун I. В. Технологія розвитку критичного мислення і сучасний освітній процес. Педагогічна майстерня. № 1. Січень. 2018. С. 9-16.

3. Гончаренко С. Український педагогічний словник. Київ, 1997.376 с.

4. Інноваційні технології навчання від А до Я / упор. Валентина Волкова. Київ, 2011. 96 с.

5. Критичне мислення. URL: https://uk.wikipedia.org/ wiki/ критичне_мислення. (дата звернення: 16.02.2019).

6. Мартиненко С. М. Система підготовки вчителя початкових класів до діагностичної діяльності: дис. ... доктор. пед. наук : 13.00.04. Київ, 2009. 476 с.

7. Матоніна Р. Д. Розвиток критичного мислення учнів початкових класів. Харків, 2013. 175 с.

8. Наволокова Н. П. Технологія розвитку критичного мислення. Педагогічна майстерня. 2014. № 4. Квітень. C. $28-31$.

9. Паращенко I. І. Розвиток критичного мислення на сучасних уроках читання в початковій школі. Початкове навчання та виховання. 2015. № 28-29. Жовтень. С. 2-7.

10. Пометун О., Пилипчатіна Л., Сущенко І., Дюков
В. Основи критичного мислення. Навчальна програма курсу за вибором для учнів профільних класів соціально-гуманітарного напряму. Рідна школа. 2010. № 9. С. 24-36.

11. Тягло О.В. Критичне мислення: Навчальний посібник. Харків, 2008. 189 с.

12. Халперн Д. Психология критического мышления URL: https://www.e-reading.club/bookreader.php/110655/ Halpern_-_Psihologiya_kriticheskogo_myshleniya.html. (дата звернення: 10.02.2019).

13. Шквир О. Л. Логіка: курс лекцій з опорними схемами. Навчальний посібник для студентів педагогічних інститутів. Хмельницький, 2010. 42 с.

14. Шпічко Ю. О. Синквейн як прийом технології розвитку критичного мислення. Педагогічна майстерня. 2015. № 1. Січень. С. 25-28.

15. Scriven M., Paul RW Critical Thinking AS Defined By The National Council For Excellence In Critical Thinking, 1987. URL: http://www.criticalthinking.org/ pages/defining-critical-thinking/766. (дата звернення: 10.02.2019).

\section{REFERENCES}

1. Barabash, O. \& Hlynianiuk, N. (2018). Vchymosia mirkuvaty samostiino ta rozvazhlyvo [Learn to think independently and reasonably]. Primary school teacher. No.11. pp. 3-7. [in Ukrainian].

2. Batrun, I. V. (2018). Tekhnolohiya rozvytku krytychnoho myslennia i suchasnyi osvitnii protses [Technology of critical thinking development and the modern educational process]. Pedagogical Workshop. No.1 January, pp. 9-16. [in Ukrainian].

3. Honcharenko, S. (1997). Ukrainskyi pedahohichnyi slovnyk [Ukrainian pedagogical dictionary]. Kyiv, 376 p. [in Ukrainian].

4. Innovatsiini tekhnolohii navchannia vid $A$ do $Y a$ (2011). [Innovational technologies of teaching from A to I]. (Ed.). Valentyna Volkova. Kyiv, 96 p. [in Ukrainian].

5. Krytychne myslennia [Critical thinking]. Available at: https://uk.wikipedia.org/wiki/ (Accessed 16 February 2019) [in Ukrainian].

6. Martynenko, S. M. (2009). Systema pidhotovky vchytelia pochatkovykh klasiv do diahnostychnoi diialnosti [System of primary school teacher training to diagnostic activity]. Doctor's thesis. Kyiv, 476 p. [in Ukrainian].

7. Matonina, R. D. (2013). Rozvytok krytychnoho myslennia uchniv pochatkovykh klasiv [Development of critical thinking of primary school pupils]. Kharkiv, 175 p. [in Ukrainian].

8. Navolokova, N. P. (2014). Tekhnolohiia rozvytku krytychnoho myslennia [Technology of critical thinking development]. Pedagogical Workshop. No.4. April, pp. 28-31. [in Ukrainian].

9. Parashchenko, I. I. (2015). Rozvytok krytychnoho myslennia na suchasnykh urokakh chytannia $v$ pochatkovii shkoli [Critical thinking development at the modern lessons of reading in primary school].Primary Education and Upbringing. No.28-29. October, pp. 2-7. [in Ukrainian]. 
10. Pometun, O., Pylypchatina, L., Sushchenko, I. \& Diukov, V. (2010). Osnovy krytychnoho myslennia [Foundations of critical thinking]. Optional course curriculum for the Pupils of Profile Classes of SocialHumanitarian Orientation. Native School. No.9. pp. 2436. [in Ukrainian].

11. Tiahlo, O.V. (2008). Krytychne myslennia [Critical thinking]. Manual. Kharkiv, 189 p. [in Ukrainian].

12. Khalpern, D. Psykholohyia krytycheskoho myshlenyia [Psychology of critical thinking]. Available at: https://www.e-reading.club/bookreader.php/110655/ Halpern_-_Psihologiya_kriticheskogo_myshleniya.html. (Accessed 10 February 2019). [in Russian].
13. Shkvyr, O. L. (2010). Lohika: kurs lektsii z opornymy skhemamy [Logics: lectures course with supporting schemes]. Manual for the students of pedagogical institutes. Khmelnytskyi, 42 p. [in Ukrainian].

14. Shpichko, Yu. O. (2015). Synkvein yak pryiom tekhnolohii rozvytku krytychnoho myslennia [Cinquain as a method of technology of critical thinking development]. Pedagogical Workshop. No.1. January, pp. 25-28. [in Ukrainian].

15. Scriven, M., Paul RW Critical Thinking AS Defined By The National Council For Excellence In Critical Thinking, 1987. Available at: http:// www.criticalthinking.org/pages/defining-critical-thinking/ 766. (Accessed 10 February 2019). [in English].

Стаття надійшла до редакції 12.03.2019

UDC 374.014 .83

DOI:

Kateryna Binytska, Doctor of Sciences (Pedagogy), Associate Professor of the Pedagogy Department, Khmelnytskiy Humanitarian-Pedagogical Academy

Yaroslav Nahornyi, Ph.D.(Philology), Associate Professor of the Foreign Languages Department Khmelnytskiy Humanitarian-Pedagogical Academy

\section{DUAL MODEL OF PROFESSIONAL TRAINING OF THE FUTURE SPECIALISTS: BY THE EXAMPLE OF UKRAINE, THE REPUBLIC OF POLAND AND ROMANIA}

Certain aspects of introduction of the dual model of professional training of the future specialists in higher education systems of the Republic of Poland, Romania and Ukraine have been considered in the article. It is noted that the models of professional training of the future specialists of the countries of Eastern Europe have a common experience, which should be studied and used in the domestic system of higher education. It is mentioned that the dual education system, also known as a variable or double model of education, is based on the training of students for the profession, which is conducted both in educational institutions through classroom and extracurricular forms of work, and also by employers in practical training.

The domestic normative-legal base on this issue has been analysed, according to which the dual form of education was introduced and it has been accentuated that the following requirements for the professional training of the future specialists are legally established: modernization of educational programs; improving the quality of training specialists; convergence of education with labour market requirements; strengthening the role and influence of employers on education; increase of motivation for learning among pupils and students; growth of youth employment rate; reduction of the adaptation period, which graduates have at work; increasing the competitiveness of workers.

It is emphasized that in the European countries the dual system is also called alternate, bilateral, parallel, which is organized jointly by the employers and educational establishments. Characteristic features of such a model of education are: the applicant of education studies for a certain profession, specialty or qualification; the educational process takes place at the employer or in the enterprise; temporary education under the employment contract is used and there is a certain remuneration for the work done; theoretical training is organized in classroom or in extracurricular forms; the educational process ends with the receiving of qualification-profession; there is (optional) possibility to obtain additional certificates. It is generalized that the dual model of professional training should provide the student with theoretical knowledge, and there is direct contact with the labour market, which consists of: alternating educational training of students who study at the workplace and receive education at the higher education institution.

Keywords: dual education; professional training; a specialist; higher education.

Ref. 9.

Катерина Біницька, доктор педагогічних наук, доцент кафедри педагогіки Хмельницької гуманітарно-педагогічної академї Ярослав Нагорний, кандидат філологічних наук, доцент кафедри іноземних мов Хмельницької гуманітарно-педагогічної академї

\section{ДУАЛЬНА МОДЕЛЬ ПРОФЕСІЙНОЇ ПІДГОТОВКИ МАЙБУТНІХ ФАХІВЦІВ: НА ПРИКЛАДІ УКРАЇНИ, РЕСПУБЛІКИ ПОЛЬЩА ТА РУМУНІЇ}

У статті розглянуто окремі аспекти впровадження дуальної моделі професійної підготовки майбутніх фахівиів у системах вищої освіти Республіки Польщуа, Румунії та України. Проаналізовано вітчизняну 